scientist, but he recognized that the future even of the wool industry would be determined by the extent to which it used the findings of the inereasing number of chemists, physicists, engineers and biologists being trained in the universities. Fortunately the wool industry has taken full advantage of the opportunity and is now based. on sophisticated applied science and engineering.

Whoreas fifty years ago tho structure of wool was almost unknown, now, as a result largely of the work pioneered by Astbury and Speakman in Leeds and actively pursued by other groups of investigators not only in Britain but also in France, Sweden, Germany, the United States, Australia and South Africa, it is sufficiently well established to form the basis on which new and commercially significant processes have been developed and which increase the usefulness of wool. In the engineering field, processing has been rationalized and new machines such as the Raper 'Auto-leveller', the Ambler 'Superdraft' system of spinning, and the Sulzer weaving machine have been produced, while advances in biological research and animal husbandry have greatly increased the amount of wool available. The industry is progressive, modern and exciting. In Britain it is well served by an active Research Association and there are ample facilitios for training personnel in technical colleges and in universities. The modern industry is based on sound science and ingenious invention and its problems are challonging ones. It offers, and will continue to offer, intellectually rewarding careers for young people with a wide variety of talents, for fow industries require the services not only of seientists, technologists, engineers and economists but also of men and women with a true flair for style and design.

In a wider context a note such as this would not be complete without some mention of the fundamental scientific consequences of the researches on the structure of wool, for out of these have emerged important aspects of the new science of molecular biology. Moreover, the complexity of wool - an insoluble protein - necessitated the development of new techniques to obtain information about the sequence and proportions of the constituent amino-acids. One of these procedures, that of partition chromatography, was developed by A. J. P. Martin and R. L. M. Synge working in the laboratories of the Wool Industries Research Association, and for this work they were awarded the 1952 Nobel Prize in Chemistry.

Until just before his death Prof. Barker retained an active interest in textile education and developments, and he must have been gratified to observe the ever-increasing significance of science in the industry which meant so much to him.

C. S. WHEWELL

\section{Dr. Peter Pringsheim}

AFrer a long life-time devoted to the subject of luminescence, Dr. Peter Pringsheim died on November $20,1963$.

He was born on March 19, 1881, son of Prof. Alfred Pringsheim, mathematician, of Munich, and took his doctorate there under Röntgen in 1906 with a dissertation on "The Minimum Potential for Spark Dischargo". Periods of work at Göttingen, Cambridge (under J. J. Thomson) and Berlin followed, and the summer of 1914 found him in Australia with the meoting of tho British Association for the Advancement of Science. Here he was interned for the period of the First World War, after which he returned to Berlin, married his Belgian wife in 1923, and was appointed full professor of the university in 1930. Three years later the Hitler régime caused him to leave Germany for a chair in the University of Brussels, which he retained until 1949. However, he was caught up with again in 1940 by the invasion of Belgium in the Second World War, and sent to internment in the south of France, but obtained liberation the following year on an American visa to carry out research at the University of California, Berkeley. His knowledge of the lumi- nescence of uranyl compounds was doubtless the reason for his transfer to the Univorsity of Chicago, during 1942-44, and again as visiting professor during 1946-47, after an interval as director of research, Ray Control Co., Pasadena.

During 1947-55 he occupied the post of senior scientist, Argonne National Laboratory, Chicago, retiring at the age of seventy-five to Antwerp.

Pringsheim was an active research worker and an assiduous amasser of information from all sources on his chosen subject. Eighty publications, in fourteen journals, describe his investigations; the subjocts include the polarization of fluorescence from vapours and dye solutions; general observations on fluorescence and photochemical changes in solutions of hydrocarbons, of dyes and of uranyl compounds and metal complexes; and luminescence and colour centres in irradiated crystals. The introductory chapter in his book Luminescence (1943) exhibits his interest in the ancient history of the subject together with his precise yet light touch in description.

His first book, Fluorescenz und Phosphoreszenz im Lichte der neueren Atom-theorie (Springer, Berlin, 1921; third edition, 1928), was written during his time of internment in Australia, and remained for many years the only authoritative book on the subject. Important contributions were made also in. Volumes 19, 21 and 23 of the Handbuch der Physik (Springer, Berlin). In 1943 he produced, in collaboration with Marcel Vogel, Luminescence of Liquids and Solids (Interscience), and finally, in 1949, his massivo work, Fluorescence and Phosphorescence (Interscience), dedicated to James Franck. This book, containing more than 1,900 references to the literature, has been of immense value to recent workers in this subject of increasing topical interest, not only because of its completeness and reliability, but also because of the clear and critical exposition of the facts in a manner so characteristic of the author.

Pringsheim, during his life-time, was aequainted or associated with all the leading figures carrying out work on luminescence, such as James Franck, Pohl, Hertz, Jablonski, Terenin and Vavilov, and followed its transformation from vague pre-quantum ideas to present-day concepts, constantly both forward and backward looking. Without him the subject would have lacked a great teachor and adviser.

In 1937 he was elected Foreign Momber of the Polish Academy. His wife survives him.

E. J. Bowen

\section{Dr. A. A. Benedetti-Pichler}

Dr. Anton Alexander Benedetti-Pichler, who died suddenly on December 10, 1964, was a pioneer in the establishment of microchemistry in the United Statos.

Born in Vienna, Austria, in 1894, Dr. Pichler received degrees at the Technische Hochschule in Graz, where he worked for many years with the pioneer in microchemistry, Hofrat Friedrich Fmich. It was during his years with Dr. Emich that Pichler learned from him the importance of extreme attention to minute details, which showed up through all his life in his contributions to the field of microchemistry and to general analytical techniques. "During the early years," he once said, "Emich was a very exacting chief, and I did not have an easy time. Later, he relaxed when he found that $\mathrm{I}$ really tried to do my best."

After obtaining tho venia legend $i$ in analytical chemistry, Dr. Pichler decided to take up permanent rosidence in the United States in 1929, in order to introduce the inorganic microchemical working procedures of Dr. Emich and his co-workers there, and to raiso the standards of the analytical chemist.

Mainly through the consistent efforts of Dr. Pichler in the 1930's there have beon laid tho solid foundations of the Microchemistry Section in the American Chemical 